\title{
A Culture of Violence? Women in Twentieth Century Bengal
}

\author{
Senjuti Jash \\ Independent Researcher, Kolkata,India,senjutijash.2207@gmail.com
}

\begin{abstract}
Violence is one of the primeval instincts of human kind. It is not restricted by spatio-temporal frontiers and majority of human beings, irrespective of their gender, age, nationality, orientation, etc. are subjected to some form of violence during their lives. However, as the societal conditions have always enabled the subjugation of the "weak" by the "powerful", violence against women has been identified globally as one of the most systematic and widespread human rights violations. Using three short stories authored by Jagadish Gupta, Tarashankar Bandyopadhyay, and Mahasweta Devi in twentieth century Bengal as case studies, this paper seeks to examine the diverse trajectories of violence perpetrated against women in the aforesaid period. Analysing particular modes of violence like dowry-based homicide, witch-hunting, and rape as political instrument of oppression, this study intends to qualify Michael Taussig's thesis on "culture of terror" by situating it against the wider backdrop of the "culture of violence" and the discourses of resistance that simultaneously emerged in twentieth century Bengal.
\end{abstract}

KEYWORDS: women, patriarchy, superstition, caste, class, culture, violence, resistance, twentieth century, literature, Bengal

\section{Introduction}

This paper intends to approach the issue of violence against women by analysing its portrayal in twentieth century vernacular literature of Bengal. In the process, it will particularly focus on three shortstories authored by Jagadish Gupta, Tarashankar Bandyopadhyay, and Mahasweta Devi to illustrate how the trajectories of violence committed against women permeated the social, political, and economic realities of twentieth century Bengal. While further consolidating a space for re-enforcing the evils of patriarchy, illiteracy, superstition, and class divisions, violence also generated counter-discourses of resistance.

Firstly, by taking up Jagadish Gupta's "Payomukham" as the case study, this essay will examine the economic grounds for violence inflicted on women in twentieth century Bengal. It seeks to reflect on how the roots of patriarchal dominance enabled the creation of both an individual and familial space for perpetrating violence in the First World War ravaged society. Here, especially middle class women whose families had the ability to pay a considerable sum of dowry and yet were not socially privileged were subjected to profound physical and mental torture, leading to numerous deaths. Secondly, as the narrative of Tarashankar Bandyopadhyay's "Daini" reveals, women from the lower sections of the society were particularly exposed to the brunt of social superstition and violence. Local superstitions and myths constructed a space for psychological apprehension, resulting in the identification of poor, orphan women with physical deformities as witches or evil spirits. In turn, they were either socially ostracised or beaten and burnt to death. Collective social violence against women in Bengal were thus particularly aimed at lower sections of the society who did not have the social, economic, or political mileage to generate a counter-narrative to these discourses of superstition and violence. Thirdly, this paper intends to address the question of political violence by appraising Mahasweta Devi's "Draupadi". This narrative reveals how the backdrop of political movements like that of the Naxalite Movement of Bengal was employed to engender a space for physical and mental oppression of women belonging to the lower classes of the society. Moreover, this paper will also examine how rape emerged as a weapon of intimidation and torture at both individual and collective level. However, it is interesting to note here that while addressing the rationale behind violence, these narratives also reveal trajectories of resistance, thus breaking the silence imposed by dominant discourses.

Conclusively, by using the primary sources, this essay seeks to qualify Michael Taussig's thesis on "culture of terror" to elucidate how the spaces engendered by economic, social, and political realities of twentieth century Bengal were themselves evidence of the process whereby a culture of violence against 
women was created and sustained, given the dearth of counter-narratives. However, as voices of resistance emerged, the gaps between binaries like "victim-victimiser", "dominant-marginalised" were considerably bridged, thereby subverting this culture of violence.

\section{Situating "Women" in Nineteenth and Twentieth Century India: A Historical Overview}

The advent of British rule in the Indian subcontinent brought significant changes not only in the political and economic realm but also in the socio-cultural sphere. Throughout the nineteenth century, numerous reforms were initiated by the British government, often in close collaboration with the educated natives. Though the criminalisation of Sati, propagation of widow-remarriage, restrictions on child marriage, and emphasis on women's education had a favourable impact on the status and condition of women in Indian society, these reformist actions had some inherent flaws too. The predominantly male native reformers hailed mostly from the upper Hindu castes and their elite belonging often created a rift between their ideologies and the general acceptance of their reforms on the part of the masses. As such, the voices of lower castes and other minority religions were largely absent from the wider discourses on social reform in nineteenth century India (De 1995, 16). Moreover, while these efforts encouraged more women to step out from the realm of the private sphere to that of the public, the disparity in gender equations prevailed. The new bourgeoisie which was the recipient of Western education attempted to emulate the colonialists' socio-cultural practices, but their reforms in the field of gender practices often reiterated female subjugation through a new form of patriarchy. Earlier, women were only subjugated by the male members within the domain of the household; now, they were placed at the lowest position in the socio-political hierarchy where both the colonial masters and the native men exerted their hegemony over them. The new rights granted to women in the public sphere, therefore, further masked and reinforced the private-public dichotomy as they devalued the significance of women's subordination at home (Sarkar and Sarkar 2008, 1-6). However, it is necessary to note here that while women of upper and middle classes were the most repressed by patriarchal authority and needed to learn modalities of reorientation, non-elite women had always constituted part of the menial and agricultural working classes in India, and therefore had always possessed a greater degree of agency, if not of formal education (Sen 2004, 190-91).

The last few decades of the nineteenth century underwent a political shift from moderate nationalist sentiments to militant nationalism and revivalist Hinduism as resistance against reformist activities on the part of the colonial state radically increased. In order to counter the cultural impact of colonialism, there was a deliberate acclamation of the "great" women of the past. While some reformers simply held wars and invasions responsible for the decline of the status of women in contemporary times, others traced the decline back to the Vedic Age (Heimsath 1964, 114-15). Majority of the reformers, however, blamed the Muslim rule. Disregarding critical facts that rulers like Akbar attempted to abolish atrocities like Sati and that Islamic law accorded women a higher status than Hindu law, they claimed that restrictions on female liberty were responses to the Muslim threat to women's safety in the medieval period. These debates and discourses over socio-cultural issues thus identified women as either victim or heroine, curtailing the element of identity and agency. As Lata Mani has pointed out, "Tradition was thus not the ground on which the status of women was being contested. Rather the reverse was true: women in fact became the site on which tradition was debated and reformulated" (Mani 1990, 117-18).

However, with the advent of popular politics and mass movements at the dawn of the twentieth century, the impact of cultural nationalism and militant nationalistic tendencies weakened. Leaders like Gandhi, Nehru, Subhas Bose, and Sarojini Naidu paved the way for women to play active roles in the fight for independence and the focus of gender-based reforms became more comprehensive as it widened to include women from other social strata and religions. Endeavours of the Faraizi reformers and the expansion of female education in Urdu led to the emergence of several female Muslim reformers in North and East India in the twentieth century who furthered the issue of female education and protested against the "absolute female seclusion" practiced in Islamic society. Several other reforms in the field of inheritance and marital laws were initiated as communalism engendered a space for "competitive mobilisation", thereby rendering women a significant constituency (Sarkar and Sarkar 
2008, 8). The demand for suffrage and the subsequent movements for political equality further consolidated the position of women in the public/civic sphere. However, opponents of the movement often argued that the Indian women's demand for suffrage was an artificial import from the West and a hazard to the primeval customs and traditions of India. Eventually, the movement had to align its ideals with that of the nationalist concerns. As Southard $(1993,397)$ remarks, "Suffragist ideals had to be justified in Indian terms and linked to the nationalist issues of political rights and colonial status which dominated public discourse in the twenties and thirties in India." In spite of the fact that the condition of women in Indian society improved throughout the nineteenth century and the first half of the twentieth century, as seen in the aforesaid discourses, the extent to which women could actually exert their rights of autonomy is debatable. The subject of the reforms often turned out to be the "women" themselves, instead of the socio-cultural conditions that hindered their progress (Pande 2018, 5).

While political independence brought freedom from colonial rule in 1947, it was also accompanied by a variety of problems in other aspects of life, often with violent consequences. The Partition led to communal violence and the death and displacement of millions of people across the Indian subcontinent. India's war with China and Pakistan in the 1960s and 70s, followed by the emergence of militant Naxalite movements and regional separatist insurgencies in different regions of India, further crumbled the Indian economy. According to Rekha Pande $(2018,7)$, "This period from the late sixties has been marked by economic crisis and stagnation, rising prices, increasing landlessness and generalised discontent both in rural and urban areas." Religious tensions, casteism, and socio-economic dislocation within the territory of India generated an atmosphere of violence which went on to affect women the most. And, it is against this historical background that this paper will appraise the discourses of violence against women in twentieth century Bengal (undivided Bengal before 1947 and the state of West Bengal in independent India).

\section{Chronicles of Violence against Women: Viewing through the Lens of Twentieth Century Vernacular Literature of Bengal}

The 1993 United Nations Declaration on the Elimination of Violence against Women, defined the term "violence against women" as "any act of gender-based violence that results in, or is likely to result in, physical, sexual or psychological harm or suffering to women, including threats of such acts, coercion or arbitrary deprivation of liberty, whether occurring in public or in private life" (United Nations 2000, 1-7). Globally, violence against women is identified as "one of the most systematic and widespread human rights violations". As this form of violence is embedded in gendered socio-cultural structures rather than personal or random acts, it "cuts across age, socioeconomic, educational and geographic boundaries, affects all societies, and is a major obstacle to ending gender inequality and discrimination globally" (Aleem 2013, 52).

Social ills like casteism, superstition, and illiteracy and forms of religious violence and armed conflict elevate the likelihood of violence committed against women in India. As such, it is necessary to examine the interaction of factors like class, gender, caste, ethnicity, religion, and other particularities to comprehend the conditions that instigate violence against women in regions like Bengal. One of the most prominent sites where violence against women is perpetrated is the family, particularly in the form of dowry related torture and homicide. Though Dowry Prohibition Act, 1961 prohibits the payment of any form of dowry on the part of the family of the bride to that of the groom, it is still a widespread custom practiced in regions like Bengal. Dowry demands often tend to exceed the financial capacity of a bride's family. And, when the bride's family is unable to afford the dowry demanded, the new bride is subjected to physical and psychological torture by the family of the groom, which often leads to violent ends (Anderson 2007, 154-70). The rate of violence committed against socially ostracised groups and the marginalised castes and tribes in Bengal is also very high. These socially oppressed people are predominantly victims of violence inflicted by the upper castes of the society. The women of these communities are particularly targeted as they are both socio-politically and economically vulnerable. Witch-hunting is a common form of socially sanctioned violence in Bengal against nonconformist women, particularly in the tribal areas. These practices are often deemed necessary to remove the perceived threat as local communities are influenced by paranoia and superstitions to participate in such 
acts of violence (Roy 1998, 136-37). Moreover, discrimination based on gender also intensifies during periods of armed conflict. In Naxal (Maoist) affected states like West Bengal, reports of government security forces raping local villagers during the operations to subdue the insurgent groups often emerge. In these cases, women emerge as direct victims of sexual violence like rape and mutilation, abduction, and displacement. At the same time, they are exposed to the trauma of loss and destitution (CAVOW 2006, 18-19). As these narratives reveal, the range of the forms of violence inflicted on women is quite extensive. While entities like the government, non-profit organisations, social activist groups, etc. deal with these issues first-hand, works of literature address these issues through the mode of storytelling, which often captures the attention of diverse sections of population and disseminates these concerns far and wide. In the historiography of South Asia, sources like myths, legends, chronicles, folklores, etc. often function as the primary material for the writing of "history" or itihasa (Thapar 2011, 553-59). As such, historians often employ diverse genres of fiction like the novel or the short story as source material and examine the portrayal of societal issues and conditions from a historical perspective. Here, this paper will particularly focus on three short stories authored by Jagadish Gupta, Tarashankar Bandyopadhyay, and Mahasweta Devi to examine the specificities of violence perpetrated against women in twentieth century Bengal.

\section{A Study of "Payomukham": Economic Grounds for Perpetrating Violence}

The short story "Payomukham", authored by Jagadish Gupta, was first published in the year 1927. It narrates the story of a native doctor named Krishnakanta who murdered two of his daughters-in-law in secret using his knowledge of medical science and attempted to murder the third to exact dowry repeatedly from the families of the brides. Set against the background of Bengal during the First World War, this story has attempted to portray how inopportune economic prospects and the roots of patriarchal domination propelled a person committed to the oath "do no harm" to perpetrate murders in cold blood.

In the narrative, Krishnakanta forced his elder son Bhootnath into the profession of Ayurveda medicine to elevate his demand as a prospective suitor. However, given that Bhootnath's academic prospects were unpromising, he had to spread several lies within the social circle that Bhootnath was a highly accomplished scholar who had received his education in Kolkata. Eventually, Bhootnath got married to a nine year old girl named Manimalika and Krishnakanta received a substantial amount of 700 rupees as dowry (Gupta 1958, 480-83). By commodifying his son, Krishnakanta thus not only consolidated his economic status but also used the dowry received as a means of purchasing social prestige, which often translated into upward mobility in the class-based society of twentieth century Bengal. If we look at the records on dowry-related violence, it is observed that the occupations of the husbands are usually concentrated around middle and lower level jobs. Moreover, the negligible number of unemployed and unskilled men in this data proves that a certain level of qualification on the part of the groom was requisite for their family to demand a significant amount of dowry (Prasad 1994, 78).

When a young bride enters the household of her husband after marriage, she is expected to abide by the orders of not only her husband, but also her parents-in-law and often siblings-in-law. As such, she is simultaneously placed under multiple hierarchies of command as a wife, daughter-in-law, sister-inlaw, and mother in the patrilocal residence. Any member of the husband's family can subject her to humiliation and reprimand her for any form of non-compliance and infractions (Purkayastha, Subramaniam, Desai, and Bose 2003, 517-18). Before reformist actions under colonial rule placed some restrictions on child marriage, girls were usually married before reaching puberty. However, with the gradual entrenchment of colonial culture in the Bengali middle class psyche from the late nineteenth century, urban families tended to marry their daughters after they had attained puberty and a certain level of basic education. As Bharati Ray (1991, 3015-16) notes, "This undercurrent of hostility in a traditional joint household was intensified by women's growing individualism, personal ambition. The mother-in-law versus the daughter-in law syndrome perhaps constitutes the most traumatic powerdrama in the domestic pale of a joint family." Given that the bond between a mother and son is particularly strong in India, both the wife and the mother engage in a power struggle to gain/retain control over the son after he gets married. The only identities of a bride that are considered to be socially 
acceptable are that of a dutiful wife and a mother. The conjugal needs of the bride as a "woman" are completely overlooked. As the newly educated generation of brides tended to be more vocal and autonomous, they were often perceived as threats by the mothers-in-law. Quoting Ray $(1991,3018)$, "Whereas the child-wife of the earlier era, married young and socialised to obey, endeavoured to ingratiate the elderly female authorities and even though begrudging the mother-in-law's dominance, could hardly air her rancour, the new women openly began to resent the hierarchical authority-structure, and put forward their own views in domestic matters." This contrast can be explicitly observed in the treatment of the family towards Bhootnath's first and second wife respectively. Given that Manimalika was still a child when she got married, Krishnakanta's wife Matangini did not perceive her as a threat. She was not allowed to voice her opinions in the matters of the household and was often chastised and disciplined by her mother-in-law and her brother-in-law Debnath, who was almost the same age as her. Bhootnath's second wife, on the other hand, was an educated young woman. She often clearly expressed her viewpoints regarding the profession of her husband, her necessities and discomfort, household chores, etc. Matangini and Debnath both considered her to be vain because Anupama was comfortable with her beauty and sexuality. Moreover, as Debnath could no longer exert his dominance over the new bride, he often lodged complaints against her with his parents. While Bhootnath perceived Manimalika as his play mate, he regarded Anupama as his companion. And this destabilisation in the hierarchy of the household engaged Matangini and Anupama in a power struggle over Bhootnath. Krishnakanta, on the other hand, did not interfere directly in the management of the household. Although, whenever he had to confront any economic crisis because of losses encountered in business, he patiently waited for his daughters-in-law to display signs of any sickness. Under the pretence of treating them, he skilfully murdered them by feeding them poison so that he could get his son re-married for dowry, which would momentarily cover his economic necessities (Gupta 1958, 483-88). Therefore, it is apparent that there is a firm connection between forces of global economy, increasing consumerist desires, and dowry demands. Here, this paper also intends to highlight the fact that while the explicit form of dowry-based violence resulting in homicide is easily perceptible in these narratives, it often leads to the de-emphasis of the subtle forms of domestic violence inflicted through the means of psychological oppression and intimidation.

Families in Bengal, particularly the ones belonging to the middle class, attempt to cultivate different qualities in their children, irrespective of their gender, to ensure that they will be viewed as attractive prospects during marriage negotiations. Furthermore, several non-economic criteria also influence the terms of the negotiation between the two families involved. As Willigen and Channa remark (1991, 370), "Marriage is a process by which two families mutually evaluate each other. The outcome of the negotiations is an expression of the relative worth of the two persons, a man and a woman, and, by extensions, the worth of their respective families. This estimation of worth is expressed in marriage expenditures, of which dowry is but a part." A woman's value in her husband's family is significantly enhanced if she is accompanied by a significant amount of dowry. Moreover, this mode of payment is often open-ended and can be demanded several times during the first few years of the marriage. Quoting Prasad (1994, 78), "Since, dowry expresses the hierarchical relations of marriage in India and the lower status of the woman and her parents, the bride becomes a conduit for the flow of gifts and money to the groom's family. Probably that is the reason why the bride becomes a target for emotional abuse and violence in the first few years of marriage at her in-laws' family." As the plot of "Payomukham" advances, it is seen that Bhootnath was no longer interested to get married again after the tragic death of his previous wives. Krishnakanta grew thoroughly impatient because the diminishing status of his wealth not only led to his authority being undermined in the society but also within the walls of the household. However, Krishnakanta eventually convinced his son to re-marry and received a hefty sum of 800 rupees as dowry. Because the new bride Binapani was dark-skinned, Krishnakanta forced her family to pay an additional sum every month as compensation for her imperfections (Gupta 1958, 492). The third bride Binapani was thus particularly viewed by Krishnakanta as a productive capital asset because the monthly payments made by her family to compensate for her dark skin can be placed in an analogous paradigm with the concept of monthly interests acquired from capital investment. Moreover, the economic stability of the groom ensured that the family of the bride would cater to each 
and every demand of the groom's family for the sake of their daughter's security and happiness. And this apparent economic stability enabled Krishnakanta to get his son married for a third time, even after both his previous wives had encountered sudden illnesses and deaths.

While the narrative primarily explores the conditions of violence, it is interesting to note that "Payomukham" also engages with the discourse of resistance. When Bhootnath found out that his father was exacting additional sums of dowry as compensation for his dark-skinned wife, he assured his wife's family to discontinue the payment. Moreover, when Binapani contracted cholera and Krishnakanta attempted to murder her, he intervened and recommended his father to commit suicide by consuming the same poison which was originally intended for his wife (Gupta 1958, 492-94). There are female voices of resistance too. Anupama defied the traditional patriarchal hold by adhering to non-conformism and voicing her thoughts and opinions in everyday life. Hence, the voice of resistance against violence can emerge from any individual, irrespective of the gender or position, even when the violence is directed at a particular gender.

\section{Analysing "Daini": Trajectories of Social Violence}

Tarashankar Bandyopadhyay's "Daini" stands out as an emblem of silent resistance. First published in the Prabashi magazine in 1940, it narrates the story of a lower caste woman named Surodhuni. Socially humiliated and ostracised throughout her life for her unconventional appearance, she was branded as a witch from a very young age. Given that misfortunes and deaths often occurred in her vicinity, these coincidences and the collective social brunt eventually led her to believe that she was genuinely responsible for these incidents. Leading a solitary life on the outskirts of a village, she was displaced from one place to another throughout her life. Eventually, she died after being impaled upon a sharp branch of a tree while fleeing from the wrath of the local people during a storm (Bandyopadhyay 1952, 476-89).

Surodhuni lived in a small hut which faced a huge expanse of dry and barren land. The people of the village Chhati-phata were convinced that her malevolent gaze had sucked out the moisture from the land and the adjacent sources of water. Moreover, when young Surodhuni had started salivating at the sight of another young boy having a mango and the boy developed a stomach ache, the parents of the boy were convinced that she was a witch and her gaze had exposed their son to the sudden illness. Profound physical and verbal abuse eventually persuaded orphan Surodhuni of her guilt and she begged before God to reform her evil sight or to make her blind. Incidents like these occurred abundantly throughout her life. Eventually she was even accused of killing her own husband by drinking his blood, while he had actually died because of developing tuberculosis. Given that diseases like cholera and tuberculosis could make the victims cough up blood, people branded Surodhuni as a vampire in her youth (Bandyopadhyay 1952, 476-87). When rationally analysed, these incidents turn out to be coincidences, often resulting from a bad diet, environmental condition, or contraction of a chronic epidemic. However, societal pressure, prevalent superstition, and lack of education eventually turned an ordinary human being against her own self. She was so convinced of her guilt that it managed to silence her voice against any form of abuse she encountered. The background which conditions the economic subjugation, sexual oppression, and persecution of orphaned, widowed, and independent/vocal women is complex. Villagers in remote corners of Bengal often accredit a range of unpleasant incidents such as accidents, sudden deaths, chronic epidemics, crop failures, etc. to witchcraft. According to Taussig (1984, 494), "It is in the coils of rumor, gossip, story, and chit-chat where ideology and ideas became emotionally powerful and enter into active social circulation and meaningful existence." Here, the recognition of a particular woman as a witch also involves an equation of gendered suppression and persecution. In tribal areas, where the occurrence of witchcraft related violence is particularly high, women do not risk the possibility of being labelled as a witch by opposing the norms and traditions practiced by the society. Local witch doctors, who are assigned the task of identifying a witch, often collude with the influential people of the area who want a particular threat to be removed. Given that illiterate and superstitious people hold the verdict of the witch doctor in high esteem, the identified woman is exposed to the brunt of collective social boycott and violence (Roy 1998, 136-43). As to why independent women and widows are particularly identified as witches, Puja Roy $(1998,144)$ remarks, 
"widows and single women are not controlled by any man, hence they have the freedom to harm others. The assumption that women are essentially evil, and that only men can control them, embodies all those values that suppress women in a patriarchal society. Violence against women is a clear indication of their degraded social status and vulnerability, and witchcraft-related crimes exemplify this."

As the narrative of "Daini" portrays, Surodhuni was repulsed by her own sight when she viewed herself in a mirror. It was her brown eyes and reddish hair which made her stand apart from others around her (Bandyopadhyay 1952, 476). Eventually, she could no longer distinguish between her own "self" and the conceived notions of the "other". Even when she attempted to help the people around her, their irrational fear often led to unfortunate incidents. For instance, she wanted to help a young man from a lower caste reconcile with his lover by offering him her silver bangles and a few rupees. However, he was so frightened at the sight of her approaching him that he attempted to run away very fast, thereby falling down and fracturing his leg. The villagers accused old Surodhuni of cursing the young man and decided to summon a witch doctor to punish her (Bandyopadhyay 1952, 485-88). The process of "othering" thus generated irrational fear in the psyche of people. Even acts of kindness were perceived as threats. As evident here, "fear" itself generated a space where fear could be re-imposed. Given that hegemony could not be established without the creation of the "other", fear and violence are portrayed as political constructs in this narrative.

Hence, it is the very potential of the power of unconventional women and their simultaneous marginality that lead to the identification of women from lower castes as witches. The lack of discernible resistance on the part of Surodhuni and the culmination of the narrative in her death thus offer a different perspective on the notion of resistance against dominant discourses. Silence has its own voice, and this is what Tarashankar's "Daini" seeks to convey. Through her death, Surodhuni herself became the medium of her freedom and agency.

\section{An Appraisal of "Draupadi": Examining Premises of Political Violence}

Mahasweta Devi's short story "Draupadi" marks a significant juncture within the discourse of feminist literature of India. First published in the magazine Parichay in 1977, the story is set against the background of Naxalite Movement in Bengal and focuses on a tribal woman named Dopdi. She and her husband were comrades of the local insurgent group and, therefore, fugitives from law. While her husband was immediately executed after he was apprehended, Dopdi's capture was followed by an elaborate cycle of torture in the form of gang rape and psychological humiliation. However, instead of succumbing to this patriarchal mode of subjugation, she used her body as the instrument of resistance, which was itself the site of her violation.

West Bengal has been one of the strongest centres of communist intellectualism since the second half of the twentieth century. The principal targets of these Leftist insurgent groups were the longestablished oppressors of the peasant communities and farm workers and they attempted to destabilise the unofficial collusion between the government and the landlords (Spivak 1981, 385). Along with the marginalised sections of the society like the tribes, Dalits, and the peasants, a significant number of women also identified with the communist struggle as they sought equality and agency. In this context, "the enforcement of binaries - solely as either perpetrators of violence or victims of violence - while viewing the role of women in conflict zones eschews our understanding the multi-layered experience of women. On the one hand, the Naxal movement has given women from India's rural and tribal belt the opportunity to take up arms and activities that have been usually reserved for men. At the same time, the external patriarchal structures are re-created and re-imposed in the form of sexual abuse, rape, denial of seats at the high tables and falling back into gendered roles once the conflict is over" (Narain 2017, 15).

Captured prisoners are usually subjected to repeated cycles of torture. Particularly when high profile prisoners are captured, the captors often take turns to inflict torture individually. In the case of women, they are repeatedly raped by the official personnel until they concede, thus signifying the triumph of patriarchal subjugation over the marginalised female. This form of political intimidation is not instigated by any individual or a group; it is often means on the part of the state to exert their control over dissenting people. Dopdi's long-awaited capture created a similar environment of enthusiasm and relief in the camp (Devi 2004, 69-70). The incapability of the General and other government personnel 
to apprehend a woman over the years actually challenged their masculine identity. As such, by engaging in the act of rape and torture, they attempted to re-establish their physical authority over Dopdi. At the same time, torture seems to have been conceptualised as a form of entertainment to break the monotony of the quotidian. Moreover, while the General was sympathetic to the doctrine of insurgents like Dopdi, he believed in the ideology that in order to destroy the enemy he had to become one (Devi 2004, 62). Thus, the fine line between the pre-conceived notions of "civilised" and "savage" gets blurred. The actions of the General actually enabled the creation of a space of violence to justify his own ends. In his attempt to interchange ranks, the physical torture and psychological humiliation that was inflicted on Dopdi under his command actually consolidated the culture of violence which his civilised intellectual self had previously condemned. When she defies the General by refusing to cover her disfigured body at the end of the narrative (Devi 2004, 70-71), she "figuratively forces her captors to confront an image of their own brutality, for which her exposed and mutilated body becomes a signifier" (Chakravarty 2012$13,130)$.

Mahasweta Devi reimagines the portrayal of mythical Draupadi by situating her in the contemporary socio-political and historical backdrop of the Naxalite Movement in Bengal. Quoting Sharma $(2017,6)$, "Instead of destroying the intricacies of myths she indulges with these deconstructive theories to eventually recast them as the metaphors of empowerment and affirmation." In the narrative, Mahasweta introduced us to Dopdi as part of a conversation between two armed personnel, who were examining the two versions of her name - "Draupadi" and "Dopdi". While the differences in pronunciation merely distinguish between the Sanskritised and the tribalised form of the word "Draupadi", Dopdi is a reimagined and demythicised avatar of the eponymous Draupadi from Mahabharata. When Draupadi's eldest husband lost her to the Kauravas in a game of dice, she did not emerge as a heroine in her own right. Though her status as a polyandrous woman situated her in an apparent position of authority over the five Pandava brothers, she was reduced to nothing but a commodity which the eldest brother staked at the game. Instead of generating her own narrative of defiance, she turned to the incarnate Krishna as the Kauravas began to disrobe her in public. It was Krishna's divine intervention that preserved the "dignity" of Draupadi in the ancient epic. The character of Dopdi, on the other hand, has been thoroughly reimagined by Mahasweta. She was easily disrobed by the armed personnel and repeatedly raped throughout the night on the day of her capture. However, she did not show any signs of mortification and questioned the guard proudly when he ordered her to enter the General's tent. As a symbol of defiance, Dopdi refused to cover her mutilated body and tore the piece of clothing she was offered. In spite of the fact that she was naked and vulnerable, she declared that there was not a single man around her who could make her feel undignified. As Dopdi pushed the General back with her bruised breasts, he was genuinely terror-stricken by an unarmed captive for the first time (Devi 2004, 69-71) Instead of relying on male intervention, Dopdi engendered her own instrument of resistance. Unlike her legendary counterpart, Dopdi countered the patriarchal construct of "sexual honour" and transformed her victimhood into agency. Overcoming the sentiments of guilt, fear, or shame that are customarily associated with rape and other forms of sexual oppression, Dopdi subverted this discourse of political violence by rendering the violence itself impotent. As Spivak (1981, 388) remarks, "She is what Draupadi - written into the patriarchal and authoritative sacred text as proof of male power - could not be." Therefore, Mahasweta Devi's "Draupadi" emerges as the representative of the marginalised sections of the society like the tribals, Dalits, and women in their quest for transcending the subaltern status and making their voices heard in the wider cultural and socio-political milieu of the nation.

\section{Concluding Reflections: A Culture of Violence?}

Picking up the thread from where we began, this paper has thus elucidated how violence perpetrated against women in twentieth century Bengal was endemic. Its pervasiveness impacted the existence of women not only within the domain of the household but also in the public sphere, irrespective of class, caste, marital status, domicile, etc. This culture of violence was not necessarily conditioned by any individual or random rationale for brutality. Rather, it was consciously cultured and sustained by the economic, socio-cultural, and political milieu of the time. In this process, it was aided by diverse 
elements like economic difficulties resulting from war, forces of global capitalism, class divisions, casteism, superstition, illiteracy, patriarchy, state-sponsored oppression, and so on.

In this context, Michael Taussig's contention on "culture of terror", developed in his analysis of Roger Casement's Putumayo Report, can be placed in a parallel framework to elaborate on the culture of violence in twentieth century Bengal. As Taussig explains, the question regarding the agency of narration influences the process of writing effectively against terror. "Terror" often becomes subjective when narrated from the point of view of a particular agent (Taussig 1984, 467). This argument can also be situated in the context of socially sanctioned violence like witch-hunting and state sponsored political violence against insurgent groups in Bengal. When examined from contrasting viewpoints, the justification for violence on the part of the villagers of Chhati-phata and that of the General undermines the narratives against violence perpetrated by them.

Moreover, according to Taussig $(1984,469)$, "Cultures of terror are based on and nourished by silence and myth in which the fanatical stress on the mysterious side of the mysterious flourishes by means of rumor and fantasy woven in a dense web of magical realism. It is also clear that the victimizer needs the victim for the purpose of making truth, objectifying the victimizer's fantasies in the discourse of the other." The elaborate process of identifying a woman as a witch and the subsequent undertaking of collective social intimidation in twentieth century Bengal was conditioned by a similar process of cultural "othering" and myth-making. Guided by superstition, illiteracy, and patriarchal regulations, the people constructed the idea of a witch to justify societal realities. In this case, the individuals labelled as witches were forced to live in such a heightened state of fear that their lack of resistance translated into "truth". And, this process of censoring existence through fear and violence dismantles the public sphere, thereby ceasing the progress of a civil society.

Taussig also argues that market pressure often acts as a trigger in the instigation of terror and torture. The lack of "commoditized social relationships", in interaction with forces of global capitalism, guides the production of torture and terror (Taussig 1984, 479). In India, there is currently a legal restraint on the commodification of domestic or familial relationships. However, such customs were not censured during the first half of the twentieth century. Aggravated by elements of capitalistic greed and destabilisation of political economy in a society ravaged by several wars, the graph of dowry-based homicide climbed significantly higher during this period.

Although Taussig talks about the importance of counter-discourses, the culture of terror is ultimately sustained in his examination of the colonised people of Columbia's Putumayo plantation. Citing that the narratives of Casement were to a certain extent fictionalised, Taussig does not partake in the task of locating narratives of resistance. As the binary between the "victim" and "victimiser" is not bridged, the ontological concerns and epistemic exercises of the colonisers transform the space of terror into the "space of death" (Taussig 1984, 471-95). On the other hand, this particular research on the culture of violence in twentieth century Bengal shows how works of fiction can generate counternarratives against the silence imposed by dominant discourses. In the face of intimidation and violence, characters like Bhootnath, Anupama, Surodhuni, and Dopdi thus engendered their own sites of resistance, thereby becoming representatives of the struggle of marginalised individuals and communities in twentieth century Bengal. As the binaries like "victim-victimiser", "dominantmarginalised" were substantially bridged, the culture of violence was also simultaneously subverted.

\section{References}

Aleem, Shamim. 2013. Women, Peace, and Security: An International Perspective. Bloomington: Xlibris Corporation. Anderson, Siwan. 2007. "The Economics of Dowry and Brideprice.” Journal of Economic Perspectives 21(4): 151-174 Bandyopadhyay, Tarashankar. 1952. Tarashankar Rachanavali, Vol. 7. Calcutta: Mitra and Ghosh Publishers.

CAVOW (Committee Against Violence on Women). 2006. Salwa Judum and Violence on Women in Dantewara, Chattisgarh: Report of a Fact-finding by an All India Women's Team. Hyderabad: CAVOW.

Chakravarty, Radha. 2012-13. "Other Histories: Gender and Politics in the Fiction of Mahasweta Devi." India International Centre Quarterly 39(3/4): 122-133

De, Amalendu. 1995. "The Social Thoughts and Consciousness of the Bengali Muslims in the Colonial Period." Social Scientist 23(4/6): 16-37.

Devi, Mahasweta. 2004. Shreshtha Galpa. Kolkata: Dey’s Publishing.

Gupta, Jagadish. 1958. Jagadish Gupta Rachanavali, Vol. 1. Calcutta: Granthalaya Private Limited. 
Heimsath, Charles H. 1964. Indian Nationalism and Hindu Social Reform. Princeton: Princeton University Press.

Mani, Lata. 1990. "Contentious Traditions: The Debate on Sati in Colonial India." In Recasting Women: Essays in Colonial History, edited by Kumkum Sangari and Sudesh Vaid, 88-126. New Jersey: Rutgers University Press.

Narain, Akanksha. 2017. "Roles and Participation of Women in Indian Left-Wing Extremism: From 'Victims' to 'Victimisers' of Violence." Counter Terrorist Trends and Analyses 9(8): 12-16.

Pande, Rekha. 2018. "The History of Feminism and Doing Gender in India.” Estudos Feministas 26(3): 1-17.

Prasad, B. Devi. 1994. "Dowry-Related Violence: A Content Analysis of News in Selected Newspapers." Journal of Comparative Family Studies 25(1): 71-89.

Purkayastha, Bandana, Mangala Subramaniam, Manisha Desai, and Sunita Bose. 2003. "The Study of Gender in India: A Partial Review." Gender and Society 17(4): 503-524.

Ray, Bharati. 1991. "Bengali Women and Politics of Joint Family, 1900-47." Economic and Political Weekly 26(52): 3015-3021.

Roy, Puja. 1998. "Sanctioned Violence: Development and the Persecution of Women as Witches in South Bihar." Development in Practice 8(2): 136-147.

Sarkar, Tanika and Sumit Sarkar. 2008. "Introduction." In Women and Social Reform in Modern India: A Reader, edited by Sumit Sarkar and Tanika Sarkar, 1-12. Bloomington: Indiana University Press.

Sen, Krishna. 2004. "Lessons in Self-Fashioning: "Bamabodhini Patrika" and the Education of Women in Colonial Bengal." Victorian Periodicals Review 37(2): 176-191.

Sharma, Nidhi. 2017. "Reinterpreting Myth in Mahasweta Devi’s Draupadi.” International Journal of English Research 3(4): 5-7.

Southard, Barbara. 1993. "Colonial Politics and Women's Rights: Woman Suffrage Campaigns in Bengal, British India in the 1920s." Modern Asian Studies 27(2): 397-439.

Spivak, Gayatri Chakravorty. 1981. ““Draupadi” by Mahasveta Devi.” Critical Enquiry 8(2): 381-402.

Taussig, Michael. 1984. "Culture of Terror - Space of Death: Roger Casement's Putumayo Report and the Explanation of Torture." Comparative Studies in Society and History 26(3): 467-497.

Thapar, Romila. 2011. "Historical Traditions in Early India: c. 1000 BC to c. AD 600." In The Oxford History of Historial Writing, Vol. 1: Beginnings to AD 600 BY Andrew Feldherr and Grant Hardy, 553-576. New York: Oxford University Press.

UN (United Nations). 2000. Declaration on the Elimination of Violence Against Women: Resolution A/RES/48/104. New York: United Nations.

Willigen, John Van and V. C. Channa. 1991. "Law, Custom, and Crimes against Women: The Problem of Dowry Death in India." Human Organization 50(4): 369-377. 